\title{
Gastrointestinal Helminth Parasites Community of Fish Species in a Niger Delta Tidal Creek, Nigeria
}

\author{
Anthony Ekata Ogbeibu, ${ }^{1}$ Christopher Ehighaukho Okaka, ${ }^{1}$ and Blessing Julius Oribhabor ${ }^{2}$ \\ ${ }^{1}$ Department of Animal and Environmental Biology, University of Benin, Benin City 1154, Nigeria \\ ${ }^{2}$ Department of Fisheries and Aquatic Environmental Management, Faculty of Agriculture, University of Uyo, \\ Uyo, Akwa Ibom State 1017, Nigeria \\ Correspondence should be addressed to Blessing Julius Oribhabor; oribhaborblessjuls@yahoo.com
}

Received 28 May 2013; Revised 13 November 2013; Accepted 4 December 2013; Published 12 January 2014

Academic Editor: Wen-Cheng Liu

Copyright (C) 2014 Anthony Ekata Ogbeibu et al. This is an open access article distributed under the Creative Commons Attribution License, which permits unrestricted use, distribution, and reproduction in any medium, provided the original work is properly cited.

\begin{abstract}
A pool of fish species in a Niger Delta tidal creek, Buguma Creek, Nigeria, collected monthly from November 2004 to June 2006, at flood tides, were examined for gastrointestinal helminth parasites. The fish species were caught with hooks and lines and cast nets. Only nematode parasites were encountered in the study. Of the 1,149 fish specimens examined, 213 (representing 18.5\%) were infected with various nematodes parasites. Dasyatis margarita had the highest prevalence rate of $66.7 \%$ ( 2 infected out of 3 examined), followed by Pseudotolithus (Pseudotolithus) senegalensis with a prevalence of $41.7 \%$ (10 infected out of 24), while the least infected were Arius gigas and Pomadasys jubelini with prevalence of $3.8 \%$ and 1.4\%, respectively. No infection was recorded in Elops lacerta, Gobius sp., Lutjanus agennes, L. goreensis, Argyrosomus regius, Sphyraena guachancho, S. sphyraena, Cynoglossus senegalensis, Sarotherodon melanotheron, Tilapia guineensis, Liza falcipinnis, Mugil cephalus, and M. curema. The nematode parasites, Capillaria zederi, and Aplectana hamatospicula had the highest prevalence of $33.3 \%$ in D. margarita. Laurotravassoxyuris sp. also had the same prevalence in Trichiurus lepturus. Goezia sigalasi had the second highest prevalence of $12.5 \%$ in P. (Fonticulus) elongatus which had the highest number examined, due to its high dominance in the water.
\end{abstract}

\section{Introduction}

Roundworms called nematodes are the most common parasites found in marine fishes [1]. Potentially all freshwater and brackish water fish may be affected, with heavier infections in predatory fish, particularly in species also utilizing fish as intermediate or transient hosts [2]. Forty (40) species of adult nematodes, representatives of families from fish in Africa, have been reported [3]. The majority occur in the alimentary system and only few enter tissues or inner cavities (Philometridae and Anguillicola, the Swimbladder) [2]. Copepods are the first intermediate host to Camallanidae, Cucullanidae, Philometridae, and Anguillicolidae. Life cycle studies of Procamallanus laevionchus and Paracamallanus cyathopharynx in Egypt revealed a development of the first three larval stages in Mesocyclops leuckarti [2]. Camallanidae give birth to first stage larvae, which are ingested by the copepods. Larvae in copepods, or other invertebrate hosts, will develop to fourth stage larvae and further into adult males and females when ingested by a suitable definitive host. Larvae ingested by "wrong" piscine hosts often survive as waiting stages (fourth stage larvae) in the gut or other tissues for a variable length of time and continue development into the adult stage if their carrier host (paratenic host) is predated by a compatible host [4]. Host specificity of nematodes is variable. Procamallanus laevionchus has been reported from fish hosts of six different families, Paracamallanus cyathopharynx only from species of Clarias, while Rhabdochona congolensis and Spinitectus allaeri have been reported from numerous diverse host species. The very host specific is species of Capillaria, most oxyurids, and the philometrids Nilonema gymnarchi and Thwaitia bagri [3,5]. Globally, there is paucity of the literature on the helminth parasites of marine and estuarine fishes, with the following records available [6-15]. The neglect of marine fish parasitology has been attributed to ignorance of the occurrence, distribution, and taxonomy of the parasites in fish [13]. 
There are reports of helminth parasite infections in freshwater fishes from a few localities in Nigeria, but a wide gap exists for the brackish water ecosystem. The only existing data on brackish water fisheries are those on Lagos lagoon [16] and Warri River [17]. Data on the gastrointestinal helminth parasites of sciaenid species [18] and the threadfin fish, Polydactylus quadrifilis [19], in the study creek, Buguma Creek, Niger Delta, Nigeria, have been published. This paper is the first to provide information on the different types of helminth parasites, their prevalence of infection, and mean abundance in the alimentary tracts of fish species community of a tidal creek in Nigeria.

\section{Materials and Methods}

The Buguma Creek is located southeast of the Niger Delta between longitude $6^{\circ} 47^{\prime} \mathrm{E}$ and $6^{\circ} 59^{\prime} \mathrm{N}$ and latitude $4^{\circ} 36^{\prime} \mathrm{N}$ and $4^{\circ} 59^{\prime} \mathrm{N}$ (Figure 1). Detailed description of the three fish sampling stations has been given [20].

The fish samples collected monthly from November 2004 to June 2006, at flood tides from three stations, were caught by the use of hooks and lines and cast nets. The fish samples were pooled, ice-packed, kept chilled under ice-blocks in a plastic cooler, and immediately transported to the laboratory. In the laboratory, fish specimens were sorted and identified to species level using the keys and descriptions of $[21,22]$.

The gut of each specimen was removed and preserved in specimen bottles containing $4 \%$ formaldehyde. Each gut was cut open and the contents washed into a petri dish using $4 \%$ formaldehyde. The contents were searched for nematodes under a low power (21-40x) binocular dissecting microscope. The sorted specimens were preserved in 4\% formaldehyde. Diverse species of nematodes recognized were sorted into different types and counted. Each type was mounted in Toluidine blue in lactophenol on a slide covered with a clean cover slip and sealed with nail vanish.

Each specimen type was photographed with Format I microstar IV Reichert photomicroscopic, model 1762. Identification of specimens to the least possible taxon was done with the aid of photographs and further examination of the specimens under the NIKON compound microscope, using taxonomic identifications $[23,24]$.

\section{Results}

A summary of infection of the fishes with the various helminth parasites is given in Table 1. Only nematode parasites were encountered in the study. Of the 1,149 fish specimens examined, 213 (representing 18.5\%) were infected with various stomach nematode parasites. Stingray, Dasyatis margarita (Family: Dasyatidae), had the highest prevalence of $66.7 \%$ ( 2 infected out of 3 examined), followed by Pseudotolithus (Pseudotolithus) senegalensis (Family: Sciaenidae) with a prevalence of $41.7 \%$ (10 infected out of 24), while the least infected were Arius gigas (Family: Ariidae) and Pomadasys jubelini (Family: Haemulidae) with prevalence of $3.8 \%$ (2 infected out of 53 ) and $1.4 \%$ (1 infected out of 72), respectively. The most dominant fish, P. (Fonticulus) elongates, had a prevalence of $23.4 \%$ (176 infected out of 753 examined). No infection was recorded in Elops lacerta, Gobius sp., Lutjanus agennes, L. goreenis, Argyrosomus regius, Sphyraena guachancho, S. sphyraena, Cynoglossus senegalensis, Sarotherodon melanotheron, Tilapia, guineensis, Liza falcipinnis, Mugil cephalus, and M. curema.

A total of 64 nematode parasite species belonging to 27 families and 7 orders were recorded. Capillaria zederi and Aplectana hamatospicula had the highest prevalence of $33.3 \%$ in Dasyatis margarita. Laurotravassoxyuris sp. also had the same prevalence in Trichiurus lepturus. Goezia sigalasi had the second highest prevalence of $12.5 \%$ in P. (Fonticulus) elongatus which had the highest number examined, due to its high dominance in the water. The parasites with the lowest prevalence of $0.1 \%$ occurred in P. (Fonticulus) elongatus, and they were Amiroides sp., Anafilaroides sp., Allintoshius sp., Aplectana Mexicana, Phacochoerostrongylus sp., Orneoascaris sp., Plicatolabia sp., Neocucullanellus sp., Neocucullanus neocucullanus, Heliconema sp., Parascarophis sp., and Ascarophis sp.

\section{Discussion}

Ingestion of larval helminth parasites by fishes is a frequent event due to the abundance and diversity of these tropically transmitted parasites in aquatic ecosystems [2527]. Comparison of the results of this study with earlier studies is limited due to the paucity of the literature on brackish water/marine fish helminth parasites, particularly on helminth community studies of fish species of an entire ecosystem. Although only nematode helminth parasites were encountered, earlier studies have reported the presence of digenea and the dominance of nematodes. The nematode, Hysterothylacium sp. (Anisakidae), and the digenean, Cryptocotyle lingua (Herophidea), were the dominant parasites in four fish species of Wadden Sea [9]. Nematodes dominated the gastrointestinal helminth parasites of white croaker, Micropogonias furnieri, from the coastal zone of the state of Rio de Janeiro, Brazil [28].

The $18.5 \%$ prevalence reported in this study is comparable to the $19.7 \%$ rate of infection recorded in the brackish water zone of Warri River, Nigeria [17]. Infection rates seem to vary greatly from one locality to the other. Factors responsible for this variations could be differences in physical and chemical conditions of the water; for instance, the present study was conducted in an environment with salinity of $0 \%-21 \%$, ranging from limnetic/oligohaline to polyhaline conditions. Pseudoterranova decipiens, for example, is not rare but rather a well-established parasite of the Antarctic fauna, which demonstrates the ability of this cosmopolitan species to complete its life cycle even under condition of subzero temperatures [10]. Current and water conditions have been considered as contributory factors [29]. Other factors are geomorphology $[10,30]$ as well as season. The component parasite communities of Scomber japonicus might be explained by the presence of different population stocks in different regions [13]. Diet of the host has been attributed to be the main factor determining the structure of the parasite 
TABLE 1: Summary of helminth parasites infection of fish species in Buguma Creek, November 2004-June 2006.

\begin{tabular}{|c|c|c|c|c|c|c|c|}
\hline S/no & Fish species & $\begin{array}{c}\text { No. } \\
\text { examined }\end{array}$ & $\begin{array}{l}\text { No. (\%) } \\
\text { infected }\end{array}$ & Parasites recovered & $\begin{array}{c}\text { No. (\%) of } \\
\text { fish infected }\end{array}$ & $\begin{array}{l}\text { Max no. } \\
\text { per host }\end{array}$ & $\begin{array}{l}\text { Mean no. per } \\
\text { infected host }\end{array}$ \\
\hline & Family: Elopidae & & & & & & \\
\hline \multirow[t]{2}{*}{1} & Elops lacerta & 1 & 0 & - & - & - & - \\
\hline & Family: Ariidae & & & & & & \\
\hline \multirow[t]{2}{*}{2} & Arius gigas & 53 & $2(3.8)$ & $\begin{array}{l}\text { Family: Oxyuridae } \\
\text { Avilandros sp. }\end{array}$ & $2(3.8)$ & 3 & 2 \\
\hline & Family: Gobiidae & & & & & & \\
\hline 3 & $\begin{array}{l}\text { Gobius sp. } \\
\text { Family: Serranidae }\end{array}$ & 1 & 0 & - & - & - & - \\
\hline \multirow[t]{2}{*}{4} & Epinephelus aeneus & 6 & $1(16.7)$ & $\begin{array}{l}\text { Family: Quimperidae } \\
\text { Paraquimperia sp. }\end{array}$ & $1(16.7)$ & 1 & 1 \\
\hline & Family: Carangidae & & & & & & \\
\hline \multirow[t]{2}{*}{5} & Caranx latus & 10 & $1(10)$ & $\begin{array}{l}\text { Family: Philometridae } \\
\text { Ichthyofilaria sp. }\end{array}$ & $1(10)$ & 1 & 1 \\
\hline & Family: Lutjanidae & & & & & & \\
\hline 6 & Lutjanus goreensis & 20 & 0 & - & - & - & - \\
\hline \multirow[t]{2}{*}{7} & Lutjanus agennes & 4 & 0 & - & - & - & - \\
\hline & Family: Haemuliae & & & & & & \\
\hline 8 & Plectorhinchus macrolepis & 5 & $1(20)$ & $\begin{array}{l}\text { Family: Trichuridae } \\
\text { Capillaria baicalensis }\end{array}$ & $1(20)$ & 1 & 1 \\
\hline 9 & Pomadasys jubelini & 72 & $1(1.4)$ & $\begin{array}{l}\text { Family: Cucullanidae } \\
\text { Cucullanus sp. }\end{array}$ & $1(1.4)$ & 1 & 1 \\
\hline & Family: Sciaenidae & & & & & & \\
\hline 10 & Argyrosomus regius & 12 & 0 & - & - & - & - \\
\hline \multirow[t]{17}{*}{11} & $\begin{array}{l}\text { Pseudotolithus (Pseudotolithus) } \\
\text { senegalensis }\end{array}$ & 24 & $10(41.7)$ & $\begin{array}{l}\text { Family: Cyathostomidae } \\
\text { Chapiniella sp. }\end{array}$ & $1(4.2)$ & 1 & 1 \\
\hline & & & & $\begin{array}{l}\text { Family: Trichostrongyliae } \\
\text { Trichohelix sp. }\end{array}$ & $1(4.2)$ & 2 & 2 \\
\hline & & & & $\begin{array}{l}\text { Family: Heterakidae } \\
\text { Africana sp. }\end{array}$ & $1(4.2)$ & 2 & 2 \\
\hline & & & & $\begin{array}{l}\text { Family: Kathlanidae } \\
\text { Spectatus sp. }\end{array}$ & $1(4.2)$ & 1 & 1 \\
\hline & & & & Family: Oxyuridae & & & \\
\hline & & & & Laurotravassoxyuris sp. & $1(4.2)$ & 1 & 1 \\
\hline & & & & Oxysomatium sp. & $1(4.2)$ & 2 & 2 \\
\hline & & & & Thaparia sp. & $1(4.2)$ & 8 & 8 \\
\hline & & & & Tachygonetria sp. & $1(4.2)$ & 1 & 1 \\
\hline & & & & Travnema travnema & $1(4.2)$ & 1 & 1 \\
\hline & & & & $\begin{array}{l}\text { Family: Subuluridae } \\
\text { Maupasina sp. }\end{array}$ & $1(4.2)$ & 1 & 1 \\
\hline & & & & Family: Ascarididae & & & \\
\hline & & & & Goezia sigalasi & $3(12.5)$ & 4 & 2 \\
\hline & & & & Goezia spinulosa & $1(4.2)$ & 1 & 1 \\
\hline & & & & Family: Heterocheilidae & & & \\
\hline & & & & Ichthyanisakis sp. & $2(8.3)$ & 3 & 2 \\
\hline & & & & Pseudanisakis sp. & $3(12.5)$ & 19 & 8 \\
\hline
\end{tabular}


TABle 1: Continued.

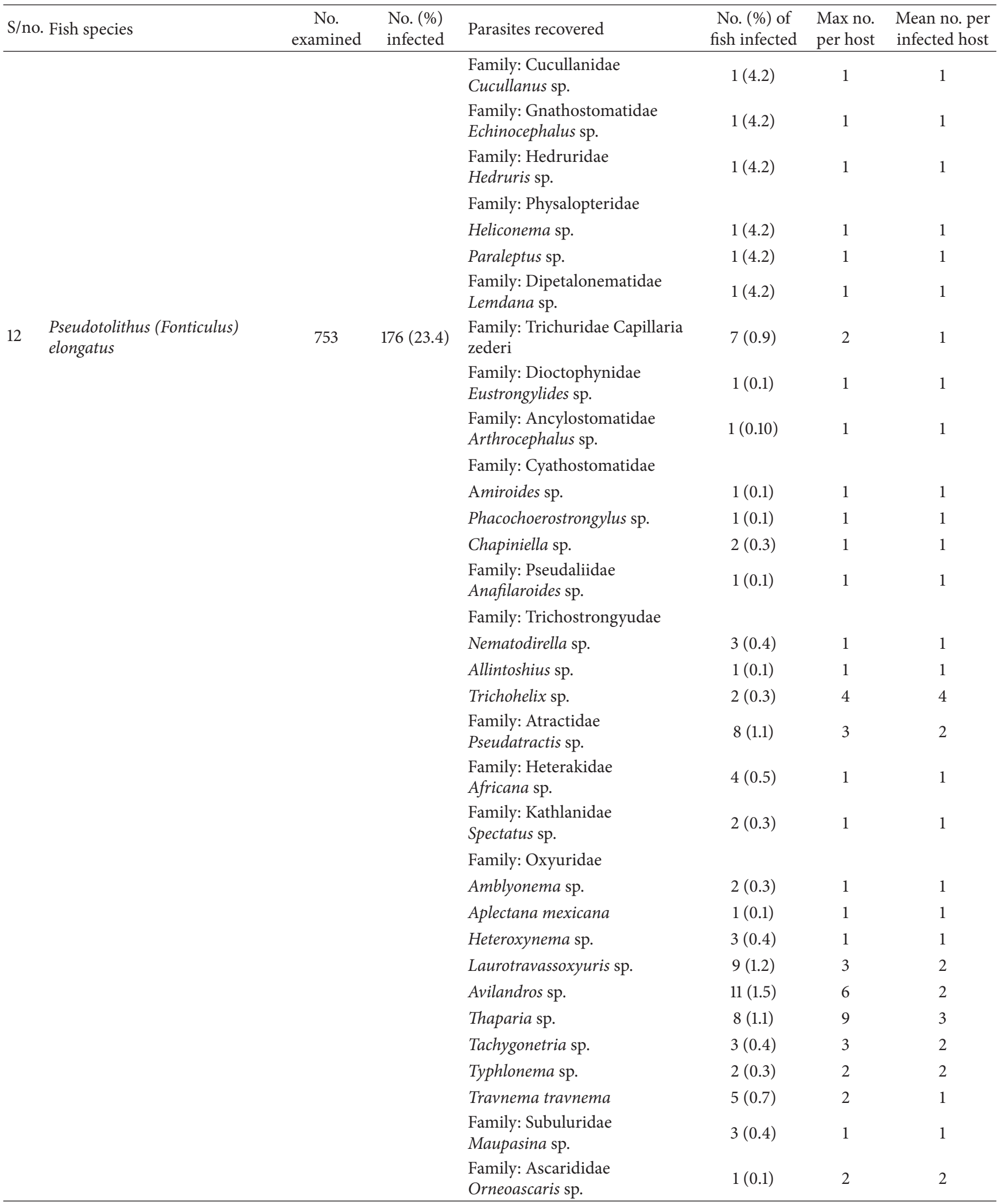


TABle 1: Continued.

\begin{tabular}{|c|c|c|c|c|c|c|}
\hline S/no. Fish species & $\begin{array}{c}\text { No. } \\
\text { examined }\end{array}$ & $\begin{array}{l}\text { No. (\%) } \\
\text { infected }\end{array}$ & Parasites recovered & $\begin{array}{c}\text { No. (\%) of } \\
\text { fish infected }\end{array}$ & $\begin{array}{l}\text { Max no. } \\
\text { per host }\end{array}$ & $\begin{array}{l}\text { Mean no. per } \\
\text { infected host }\end{array}$ \\
\hline & & & Trispiculascaris sp. & $2(0.3)$ & 1 & 1 \\
\hline & & & Goezia sigalasi & $52(6.9)$ & 14 & 1 \\
\hline & & & Geozia spinulosa & $2(0.3)$ & 4 & 3 \\
\hline & & & Neogoezia sp. & $5(0.7)$ & 3 & 2 \\
\hline & & & Family: Heterocheilidae & & & \\
\hline & & & Contracaecum sp. & $1(0.1)$ & 2 & 2 \\
\hline & & & Heterotyphlum sp. & $3(0.4)$ & 1 & 1 \\
\hline & & & Ichthyanisakis sp. & $2(0.3)$ & 1 & 1 \\
\hline & & & Pseudanisakis sp. & $43(5.7)$ & 3 & 1 \\
\hline & & & Raphidascaris sp. & $2(0.3)$ & 1 & 1 \\
\hline & & & Terranova sp. & $5(0.7)$ & 1 & 1 \\
\hline & & & Plicatolabia sp. & $1(0.1)$ & 1 & 1 \\
\hline & & & $\begin{array}{l}\text { Family: Quimperidae } \\
\text { Paraquimperia sp. }\end{array}$ & $15(2)$ & 3 & 1 \\
\hline & & & $\begin{array}{l}\text { Family: Acuariidae } \\
\text { Skrjabinoclava sp. }\end{array}$ & $2(0.3)$ & 1 & 1 \\
\hline & & & $\begin{array}{l}\text { Family: Ancyracanthidae } \\
\text { Ancyracanthopsis sp. }\end{array}$ & $2(0.3)$ & 2 & 2 \\
\hline & & & $\begin{array}{l}\text { Family: Camallanidae } \\
\text { Procamallanus sp. }\end{array}$ & $1(0.1)$ & 1 & 1 \\
\hline & & & Family: Cucullanidae & & & \\
\hline & & & Dichelyne sp. & $1(0.1)$ & 1 & 1 \\
\hline & & & Neocucullanus neocucullanus & $1(0.1)$ & 1 & 1 \\
\hline & & & Neocucullanellus sp. & $1(0.1)$ & 1 & 1 \\
\hline & & & $\begin{array}{l}\text { Family: Gnathostomatidae } \\
\text { Echinocephalus sp. }\end{array}$ & $2(0.3)$ & 1 & 1 \\
\hline & & & $\begin{array}{l}\text { Family: Haplonematidae } \\
\text { Pingus sp. }\end{array}$ & $2(0.3)$ & 2 & 2 \\
\hline & & & $\begin{array}{l}\text { Family: Hedruridae } \\
\text { Hedruris sp. }\end{array}$ & $5(0.7)$ & 2 & 1 \\
\hline & & & $\begin{array}{l}\text { Family: Physalopteridae } \\
\text { Heliconema sp. }\end{array}$ & $1(0.1)$ & 1 & 1 \\
\hline & & & Paraleptus sp. & $2(0.3)$ & 1 & 1 \\
\hline & & & $\begin{array}{l}\text { Family: Rhabdochonidae } \\
\text { Ichthyobronema sp. }\end{array}$ & $5(0.7)$ & 1 & 1 \\
\hline & & & Spinitectus sp. & $1(0.1)$ & 1 & 1 \\
\hline & & & Family: Spirurudae & & & \\
\hline & & & Parascarophis sp. & $1(0.1)$ & 1 & 1 \\
\hline & & & Ascarophis sp. & $1(0.1)$ & 1 & 1 \\
\hline & & & Family: Dipetalonematidae & & & \\
\hline & & & Skrjabinofilaria sp. & $1(0.1)$ & 1 & 1 \\
\hline & & & Lemdana sp. & $2(0.3)$ & 3 & 3 \\
\hline & & & $\begin{array}{l}\text { Family: Anguillicolidae } \\
\text { Anguillicola sp. }\end{array}$ & $1(0.1)$ & 1 & 1 \\
\hline & & & $\begin{array}{l}\text { Family: Philometridae } \\
\text { Icthyofilaria sp. }\end{array}$ & $1(0.1)$ & 1 & 1 \\
\hline
\end{tabular}


TABle 1: Continued.

\begin{tabular}{|c|c|c|c|c|c|c|c|}
\hline S/no. & Fish species & $\begin{array}{c}\text { No. } \\
\text { examined }\end{array}$ & $\begin{array}{l}\text { No. (\%) } \\
\text { infected }\end{array}$ & Parasites recovered & $\begin{array}{c}\text { No. (\%) of } \\
\text { fish infected }\end{array}$ & $\begin{array}{l}\text { Max no. } \\
\text { per host }\end{array}$ & $\begin{array}{l}\text { Mean no. per } \\
\text { infected host }\end{array}$ \\
\hline & Family: Monodactilidae & & & & & & \\
\hline \multirow[t]{9}{*}{13} & Psettias sebae & 38 & $4(10.5)$ & $\begin{array}{l}\text { Family: Trichostrongylidae } \\
\text { Nematodirella sp. }\end{array}$ & $1(2.6)$ & 1 & 1 \\
\hline & & & & Family: Oxyuridae & & & \\
\hline & & & & Oxysomatium sp. & $1(2.6)$ & 1 & 1 \\
\hline & & & & Avilandros sp. & $1(2.6)$ & 1 & 1 \\
\hline & & & & $\begin{array}{l}\text { Family: Cucullanidae } \\
\text { Dichelyne sp. }\end{array}$ & $1(2.6)$ & 1 & 1 \\
\hline & & & & $\begin{array}{l}\text { Family: Gnathostomatidae } \\
\text { Echinocephalus sp. }\end{array}$ & $1(2.6)$ & 1 & 1 \\
\hline & & & & $\begin{array}{l}\text { Family: Physalopteridae } \\
\text { Proleptus sp. }\end{array}$ & $1(2.6)$ & 1 & 1 \\
\hline & & & & $\begin{array}{l}\text { Family: Rhabdochonidae } \\
\text { Filochona sp. }\end{array}$ & $1(2.6)$ & 1 & 1 \\
\hline & Family: Sphyraenidae & & & & & & \\
\hline \multirow[t]{2}{*}{14} & Sphyraena afra & 5 & $2(40)$ & $\begin{array}{l}\text { Family: Camallanidae } \\
\text { Camallanus sp. }\end{array}$ & $1(20)$ & 2 & 2 \\
\hline & & & & $\begin{array}{l}\text { Family: Rhabdochonidae } \\
\text { Ichthyobronema sp. }\end{array}$ & $1(20)$ & 1 & 1 \\
\hline 15 & Sphyraena guachancho & 1 & 0 & - & - & - & - \\
\hline 16 & Sphyraena sphyraena & 1 & 0 & - & - & - & - \\
\hline & Family: Polynemidae & & & & & & \\
\hline \multirow[t]{8}{*}{17} & Polydactylus quadrifilis & 76 & $12(15.8)$ & $\begin{array}{l}\text { Family: Ancylostomatidae } \\
\text { Arthrocephalus sp. }\end{array}$ & $1(1.3)$ & 1 & 1 \\
\hline & & & & $\begin{array}{l}\text { Family: Cyathostomatidae } \\
\text { Phacochoerostrongylus sp. }\end{array}$ & $1(1.3)$ & 2 & 2 \\
\hline & & & & Chapiniella sp. & $1(1.3)$ & 1 & 1 \\
\hline & & & & $\begin{array}{l}\text { Family: Heterakidae } \\
\text { Moaciria sp. }\end{array}$ & $1(1.3)$ & 3 & 3 \\
\hline & & & & $\begin{array}{l}\text { Family: Oxyuridae } \\
\text { Laurotravassoxyuris sp. }\end{array}$ & $1(1.3)$ & 1 & 1 \\
\hline & & & & $\begin{array}{l}\text { Family: Ascarididae } \\
\text { Goezia sigalasi }\end{array}$ & $5(6.6)$ & 2 & 1 \\
\hline & & & & $\begin{array}{l}\text { Family: Heterocheilidae } \\
\text { Pseudanisakis sp. }\end{array}$ & $1(1.3)$ & 1 & 1 \\
\hline & Family: Trichiuridae & & & & & & \\
\hline \multirow[t]{2}{*}{18} & Trichiurus lepturus & 3 & $1(33.3)$ & $\begin{array}{l}\text { Family: Oxyuridae } \\
\text { Laurotravassoxyuris sp. }\end{array}$ & $1(33.3)$ & 6 & 6 \\
\hline & Family: Cynoglossidae & & & & & & \\
\hline \multirow[t]{2}{*}{19} & Cynoglossus senegalensis & 1 & 0 & - & - & - & - \\
\hline & Family: Cichlidae & & & & & & \\
\hline 20 & Sarotherodon melanotheron & 8 & 0 & - & - & - & - \\
\hline \multirow[t]{2}{*}{21} & Tilapia guineensis & 18 & 0 & - & - & - & \\
\hline & Family: Mugilidae & & & & & & \\
\hline 22 & Liza falcipinnis & 1 & 0 & - & - & - & \\
\hline 23 & Mugil cephalus & 2 & 0 & - & - & - & \\
\hline
\end{tabular}


TABle 1: Continued.

\begin{tabular}{|c|c|c|c|c|c|c|c|}
\hline \multicolumn{2}{|c|}{ S/no. Fish species } & \multirow{2}{*}{$\begin{array}{c}\begin{array}{c}\text { No. } \\
\text { examined }\end{array} \\
31\end{array}$} & \multirow{2}{*}{$\begin{array}{c}\text { No. }(\%) \\
\text { infected } \\
0\end{array}$} & \multirow{2}{*}{$\begin{array}{l}\text { Parasites recovered } \\
-\end{array}$} & \multirow{2}{*}{$\begin{array}{l}\text { No. (\%) of } \\
\text { fish infected } \\
-\end{array}$} & \multirow{2}{*}{$\begin{array}{c}\text { Max no. } \\
\text { per host } \\
-\end{array}$} & \multirow[t]{2}{*}{$\begin{array}{l}\text { Mean no. per } \\
\text { infected host }\end{array}$} \\
\hline 24 & Mugil curema & & & & & & \\
\hline & Family: Dasyatidae & & & & & & \\
\hline \multirow[t]{8}{*}{25} & Dasyatis margarita & 3 & $2(66.7)$ & $\begin{array}{l}\text { Family: Trichuridae } \\
\text { Capillaria zederi }\end{array}$ & $1(33.3)$ & 2 & 2 \\
\hline & & & & Family: Oxyuridae & & & \\
\hline & & & & Aplectana hamatospicula & $1(33.3)$ & 1 & 1 \\
\hline & & & & Family: Rhabdochonidae & & & \\
\hline & & & & Spinitectus sp. & $1(33.3)$ & 1 & 1 \\
\hline & & & & Family: Spiruridae & & & \\
\hline & & & & Hartertia sp. & $1(33.3)$ & 13 & 13 \\
\hline & Total & 1149 & 213 (18.5) & & & & \\
\hline
\end{tabular}

community in four fish species in the Wadden Sea [9]. Contracaecum osculatum was encountered only during the later half of the year in Sable Island harbor seals (Phoca vitulina) suggesting an association with prey species of corresponding periodicity in their distribution [11]. In the present study the parasites had the highest densities, with the highest dominance in $P$. (Fonticulus) elongatus in the dry season, corresponding with the influence of season, change in physicochemical conditions, particularly salinity, and improved availability of food prey. It is not known why there was no infection in Elops lacerta, Gobius sp., L. goreensis and $L$. aeneus, $A$. regius, S. sphyraena, S. melanotheron and T. guineensis, L. falcipinnis, M. cephalus, and M. curema. As represented by most previous workers, Camallanus sp. and Procamallanus sp. dominate infection and appear more frequent in fishes than other parasites in Nigerian rivers $[31,32]$. But in this study, Goezia sigalasi was the most dominant, infecting three species of fishes, P. (Pseudotolithus) senegalensis (12.5\%), P. (Fonticulus) elongatus (6.9\%), and P. quadrifilis (6.6\%). In this study, Camallanus sp. was only encountered in S. afra, while Procamallanus was not encountered. Pseudoterranova decipiens was observed to be the commonest nematode occurring in Sable Island harbour seals (Phoca vitulina) [11], while Anisakis sp. was the dominant species in the Club mackerel Scomber japonicus from the harbour of Mehdia Kenitra (Atlantic Coast of Morocco) [13]. Other nematode parasites encountered in this study that have been reported in southern Nigeria waters are Spinitectus sp. [32] and Cucullanus sp. [31]. Contracaecum sp., Spinitectus sp., and Raphidascaris sp. have been reported in the Atlantic Coast of Morocco [13]. Pseudoterranova decipiens, Contracaecum osculatum, and Anisakis simplex have been reported in Sable Island harbour seals (Phoca vitulina) [11], while a new nematode species, Paracapillaria epinephelus, has been described from the stomach of the marine fish Epinephelus morio (Serranidae) from the Coastal water of the Gulf of Mexico in Yucatan [33].

The availability and abundance of the definitive host (for the parasites that use fish as intermediate host) and the intermediate hosts (for the parasites that use fish as definitive hosts) could be a factor responsible for the variations in the levels of infections in the host [31]. However, the life cycle of the parasites in the locality would have to be clearly studied. Even though nematode parasites are diverse in fish species of the tidal creek, tissue change due to infection was not observed. However, some data concerning some of the parasites species recorded in the study or congeners exist in the literature. In Ascaridoidea, some data exist concerning the pathogenicity of Raphidascaris acus, and some data on the pathogenicity of anisakis larvae also exist [13]. Beside their potential pathogenicity in club mackerel, larvae of Anisakis sp. are of public concern. In 12,586 cases of anisakiasis, painful inflammation of the human gastrointestinal track was recorded in Japan, between 1968 and 1989, mainly caused by anisakid nematodes, Anisakis spp. and Pseudoterranova decipiens. The dominance of Anisakis sp. larvae, responsible sometimes for several migrans in humans, reemphasizes the importance of thoroughly cooking the mackerel before consumption by the populace. Anisakids, such as Contracaecum spp., usually infect the alimentary track of their definitive hosts, which are generally marine mammals [34]. Marine crustaceans, cephalopod mollusks, or fishes often serve as intermediate or paratenic (transport) hosts. Anisakids are not found in the flesh of fishes; they infect the visceral organs instead. Thus, these parasites are not usually harmful to the fish they infect $[35,36]$. In experimental infections of juvenile and adult chickens, mallard ducklings, mice hamsters, and rats, Contracaecum multipapillatum was not harmful. However, in marine birds, Contracaecum multipapillatum can infect the proventriculus portion of the stomach and cause lesions. This parasite can also cause granuloma in dogs that eat fish. Contracaecum multipapillatum is also capable of infecting domestic cats $[35,37]$.

\section{Conclusion}

The parasitic infection recorded in the present study is important to the fishery in the area and requires to be checked since brackish water serves as a good source of fish food 

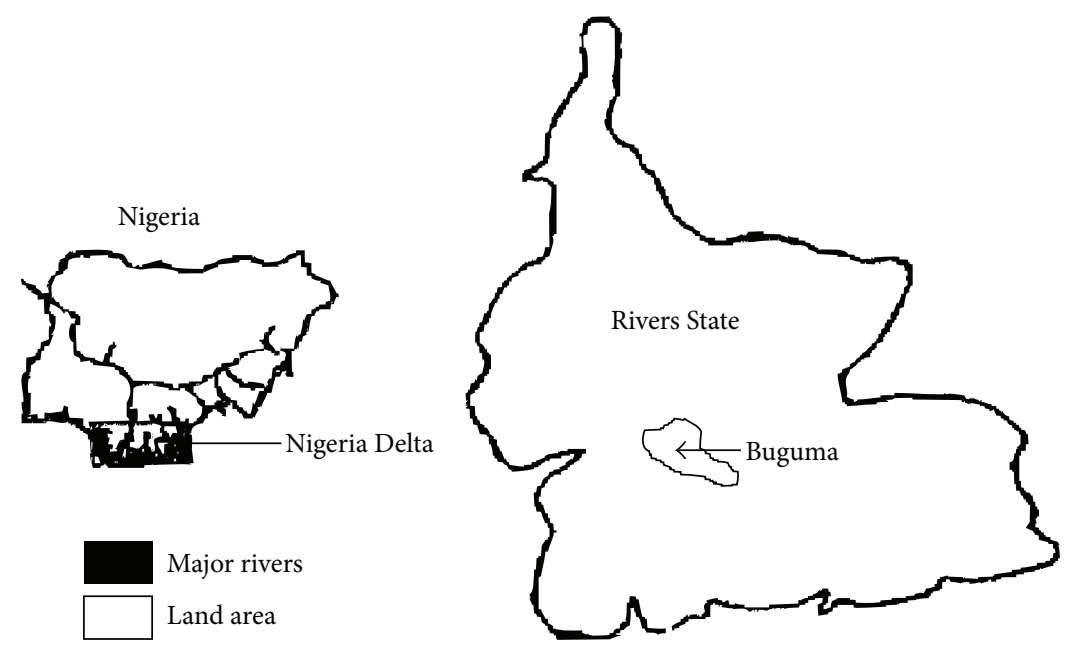

(a)

(b)

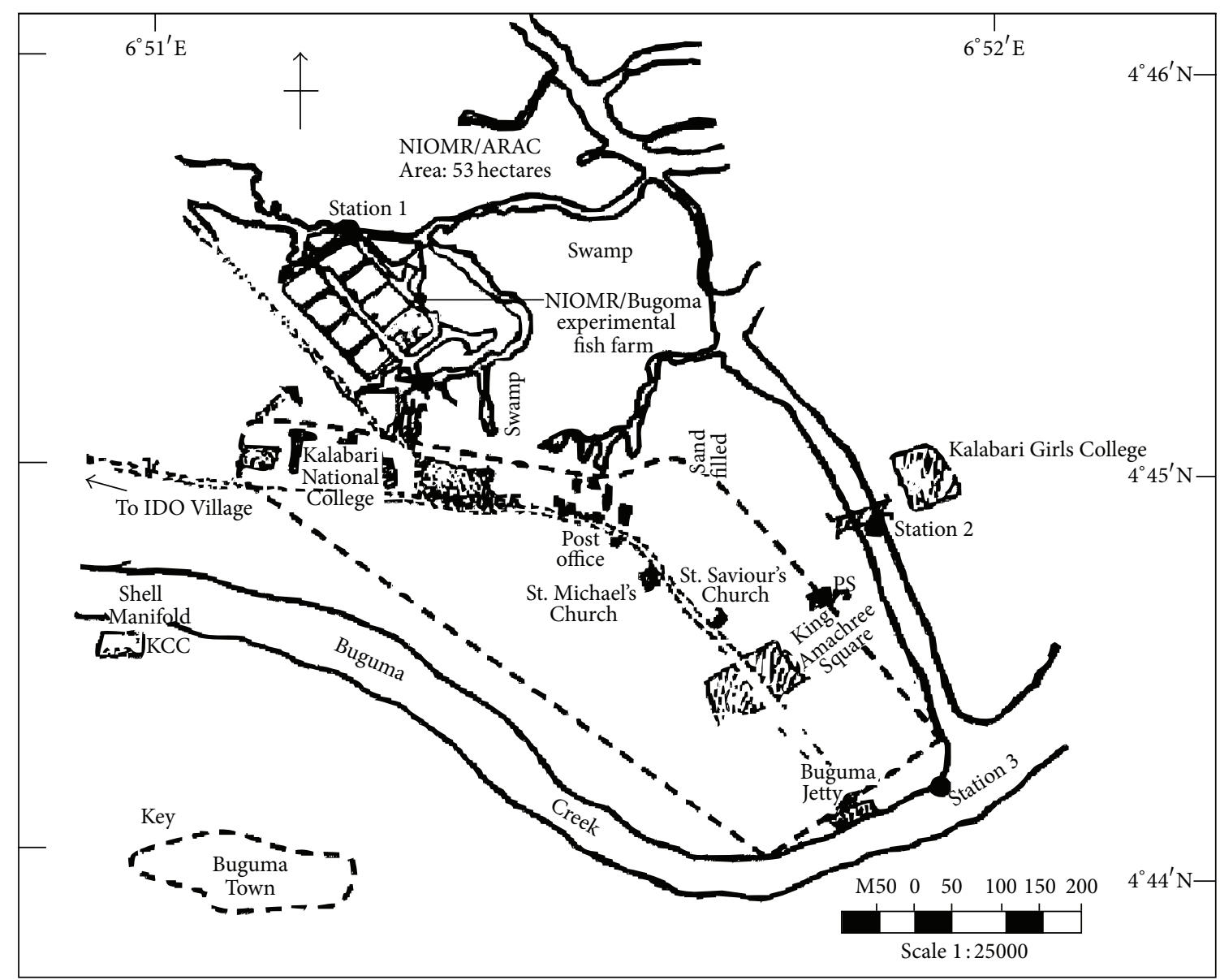

(c)

Figure 1: Map of the study area: (a) Nigeria showing Niger Delta, (b) Rivers State showing Buguma, (c) the study creek showing fish sampling stations.

for coastal communities in Nigeria, particularly in the Niger Delta. Further investigation of parasites in other organs of the fish species is recommended in order to close the wide gap existing for the brackish water ecosystem.

\section{Conflict of Interests}

The authors declare that there is no conflict of interests regarding the publication o this paper. 


\section{References}

[1] K. S. Hilderbrand, R. J. Price, and R. E. Olson, "Parasites in marine fishes, questions and answers for seafood retailers," SG Publication, Oregon State University Extension Service, Oregon State University, Corvallis, Ore, USA, 1985.

[2] I. Paperna, "Parasites, infections and diseases of fishes in Africa-an update," CIF Technical Paper 31, FAO, Rome, Italy, 1996.

[3] L. F. Khalil, "Checklist of the helminth parasites of African freshwater fishes," Technical Communication 42, Commonwealth Institute of Helminthology, St. Albans, UK, 1971.

[4] A. J. Petter, Y. A. Fontaine, and N. Le Belle, "Edute du development larvaire de Anguinicola crassus (Darcunloidea, Nematoda) chez un cyclopi de la region parisienne," Annales de Parasitologie Humaine et Comparee, vol. 64, pp. 344-355, 1989.

[5] K. F. Khalil, "Studies on the helminth parasites of freshwater fishes of the Sudan," Journal of Zoology, vol. 158, pp. 143-170, 1969.

[6] R. F. Kruegar, "A survey of the helminth parasites of fishes from Van Buren Lake and Rock Ford Creek," Ohio Journal of Science, vol. 54, no. 4, pp. 277-279, 1954.

[7] F. Sogandares-Bernal, "Some helminth parasites of fresh and brackish water fishes from Louisiana and Panama," The Journal of parasitology, vol. 41, no. 6, pp. 587-594, 1955.

[8] N. C. De and R. N. Maity, "Indocapillaria gibsoni n.g., n. sp. (Nematoda: Trichuroidea) from the estuarine fish Sillaginopsis panijus (Hamilton) of West Bengal, India," Systematic Parasitology, vol. 30, no. 2, pp. 153-159, 1995.

[9] S. Groenewold, R. Berghahn, and C. D. Zander, "Parasite communities of four fish species in the Wadden Sea and the role of fish discarded by the shrimp fisheries in parasite transmission," Helgoland Marine Research, vol. 50, no. 1, pp. 6985, 1996.

[10] H. W. Palm, "Ecology of Pseudoterranova decipiens (Krabbe, 1878) (Nematoda: Anisakidae) from Antarctic waters," Parasitology Research, vol. 85, no. 8-9, pp. 638-646, 1999.

[11] W. T. Stobo, L. P. Fanning, B. Beck, and G. M. Fowler, "Abundance and maturity of three species of parasitic anisakine nematodes (Pseudoterranova decipiens, Contracaecum osculatum, Anisakis simplex) occurring in Sable Island harbour seals (Phoca vitulina)," Canadian Journal of Zoology, vol. 80, no. 3, pp. 442-449, 2002.

[12] D. Garcia, L. Resnikoff, D. G. Buth, and P. Frost, "Intestinal Helminth Parasites of the Bay Goby, Lepidogobius lepidus (Perciformes: Gobiidae), from Bodega Bay, California, U.S.A," Comparative Parasitology, vol. 71, no. 1, pp. 86-87, 2004.

[13] M. Cisse and D. Belgyti, "Helminth parasites of club mackerel, Scomber japonicas (Honttuyn, 1782) from the harbor Mehdiakenitra (Atlantic Coast of Morocco)," Journal of Aquatic Sciences, vol. 20, no. 1, pp. 63-67, 2005.

[14] M. Gudivada and A. P. Vankara, "Population dynamics of metazoan parasites of marine threadfin fish, Polydactylus sextarius (Bloch and Schneider, 1801). From Visakhapatnam coast, Bay of Bengal.," The Bioscan, vol. 5, no. 4, pp. 555-561, 2010.

[15] M. Gudivada, V. Chikkam, and A. P. Vankara, "On a new species of Neoechinorhynchus Hamann, 1892 (Acanthocephala: Neoechinorhynchoidea Southwell et Macfie, 1925) from Indian threadfin fish, Leptomelanosoma indicum Shaw, 1804 from Visakhapatnam coast, Andhra Pradesh, India," Journal of Parasitic Diseases, vol. 34, no. 2, pp. 89-93, 2010.
[16] B. Akinsanya, O. A. Otubanjo, and C. A. Ibidapo, "Helminth biload of Chrysichthys nigrodigitatus (Lacepede 1802) from Lekki Lagoon, Lagos, Nigeria," Turkish Journal of Fisheries and Aquatic Sciences, vol. 7, pp. 83-87, 2007.

[17] M. D. Wogu and C. E. Okaka, "A comparative study of the gastrointestinal helminth parasites infection of fresh and brackish water fishes from Warri River, Southern Nigeria," African Research Review, vol. 6, no. 2, pp. 13-23, 2012.

[18] B. J. Oribhabor, A. E. Ogbeibu, and C. E. Okaka, “The gastrointestinal helminth parasites of some scianid species (croakers) in a Niger Delta mangrove creek, Nigeria," Tropical Freshwater Biology, vol. 19, no. 1, pp. 15-23, 2010.

[19] B. J. Oribhabor, A. E. Ogbeibu, and C. E. Okaka, "The gastrointestinal helminth parasites of the threadfin fish, Polydactylus quadrifilis (Family: Polynemidae) in a Niger Delta Mangrove Creek, Nigeria," International Journal of Animal and Veterinary Advances, vol. 4, no. 4, pp. 240-243, 2012.

[20] B. J. Oribhabor and A. E. Ogbeibu, "The ecological impact of anthropogenic activities on the predatory fish assemblage of a tidal creek in the Niger Delta," Research Journal of Environmental Sciences, vol. 4, pp. 271-279, 2010.

[21] W. Schneider, FAO Species Identification Sheets for Fishery Purposes. Field Guide to the Commercial Marine Resources of the Gulf of Guinea, Food and Agricultural Organisation of the United Nations, Rome, Italy, 1990.

[22] B. D. Olaosebikan and A. Raji, Field Guide to Nigerian Freshwater Fishes, Federal College of Freshwater Fisheries Technology, New Bussa, Nigeria, 1998.

[23] S. Yamaguti, Systema Helminthum, the Nematodes of Vertebrates, part II, Interscience Publishers Inc., New York, NY, USA, 1961.

[24] S. Yamaguti, Systema Helminthum, vol. 3 of The Nematodes of Vertebrates, part 1, Interscience Publishers Inc., New York, NY, USA, 1961.

[25] D. J. Marcogliese, "Food webs and the transmission of parasites to marine fish," Parasitology, vol. 124, pp. S83-S99, 2002.

[26] G. A. Parker, J. C. Chubb, M. A. Ball, and G. N. Roberts, "Evolution of complex life cycles in helminth parasites," Nature, vol. 425, no. 6957, pp. 480-484, 2003.

[27] C. Lagrue, D. W. Kelly, A. Hicks, and R. Poulin, "Factors influencing infection patterns of trophically transmitted parasites among a fish community: host diet, host-parasite compatibility or both?" Journal of Fish Biology, vol. 79, no. 2, pp. 466-485, 2011.

[28] D. R. Alves and J. L. Luque, "Community ecology of the metazoan parasite of white croaker, Micropogonais furnieri (Osteichthyes: Sciaenidae) from the coastal zone of the state of Rio de Janeiro, Brazil," Memorias do Instituto Oswaldo Cruz, vol. 96, no. 2, pp. 145-153, 2001.

[29] K. Rohde, C. Hayward, and M. Heap, "Aspects of the ecology of metazoan ectoparasites of marine fishes," International Journal for Parasitology, vol. 25, no. 8, pp. 945-970, 1995.

[30] C. J. Hayward, "Distribution of external parasites indicates boundaries to dispersal of sillaginid fishes in the Indo-West Pacific," Marine and Freshwater Research, vol. 48, no. 5, pp. 391400, 1997.

[31] C. E. Okaka, "A survey into the helminth parasites of fishes of Asa River and the impoundment at Asa dam, Ilorin, Nigeria," Rivista di Parassitologia, vol. 22, no. 3, pp. 207-214, 2005.

[32] C. E. Okaka and J. E. Akhigbe, "Helminth parasites of some tropical freshwater fish from Osse River in Benin, Southern Nigeria," Tropical Freshwater Biology, vol. 8, no. 1, pp. 41-48, 1999. 
[33] F. Moravec, E. Mendoza-Franco, and J. Vargas-Vázquez, "Paracapillaria epinepheli (Nematoda: Capillaridae) from the red grouper Epinephelus morio (Pisces) from Mexico," Systematic Parasitology, vol. 33, no. 2, pp. 149-153, 1996.

[34] G. T. Bergmann and P. J. Motta, "Infection by anisakid nematodes Contracaeum spp. in the Mayan Cichlid fish Cichlasoma (Nandopsis), Uropthalmus (Gunther 1862)," Journal of Parasitology, vol. 90, no. 2, pp. 405-407, 2004.

[35] T. L. Deardorff and R. M. Overstreet, "Contracaecum multipapillatum ( $=$ C. robustum) from fishes and birds in the northern Gulf of Mexico," Journal of Parasitology, vol. 66, no. 5, pp. 853-856, 1980.

[36] A. O. Bush, J. C. Fernandez, G. W. Esch, and J. R. Seed, Parasitism: The Diversity and Ecology of Animal Parasites, University Press, New York, NY, USA, 2001.

[37] V. M. Vidal-Martinez, D. Osorio-Sarabia, and R. M. Overstreet, "Experimental infection of Contracaecum multipapillatum (Nematoda: Anisakinae) from Mexico in the domestic cat," Journal of Parasitology, vol. 80, no. 4, pp. 576-579, 1994. 

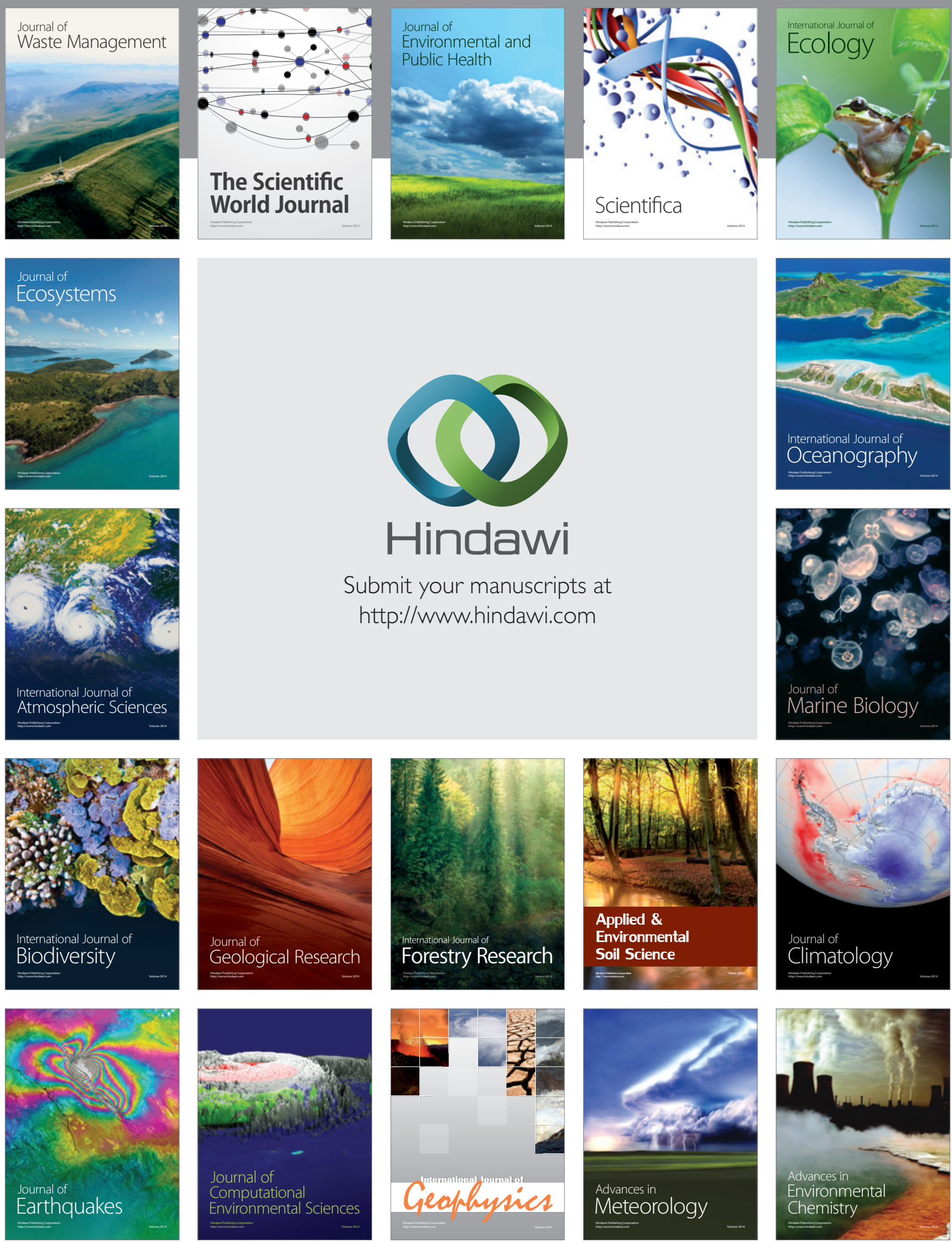